\title{
Implications of Shale Gas Development for Climate Change
}

\author{
Richard G. Newell ${ }^{*}, \ddagger, \S$ and Daniel Raimi ${ }^{\ddagger}$ \\ ${ }^{\dagger}$ Nicholas School of the Environment and ${ }^{\ddagger}$ Duke University Energy Initiative, Duke University, Box 90467, Durham, North Carolina \\ 27708, United States \\ ${ }^{\S}$ National Bureau of Economic Research, Cambridge, Massachusetts 02138, United States
}

\section{Supporting Information}

ABSTRACT: Advances in technologies for extracting oil and gas from shale formations have dramatically increased U.S. production of natural gas. As production expands domestically and abroad, natural gas prices will be lower than without shale gas. Lower prices have two main effects: increasing overall energy consumption, and encouraging substitution away from sources such as coal, nuclear, renewables, and electricity. We examine the evidence and analyze modeling projections to understand how these two dynamics affect greenhouse gas emissions. Most evidence indicates that natural gas as a substitute for coal in electricity production, gasoline in transport, and electricity in buildings decreases greenhouse gases, although as an electricity

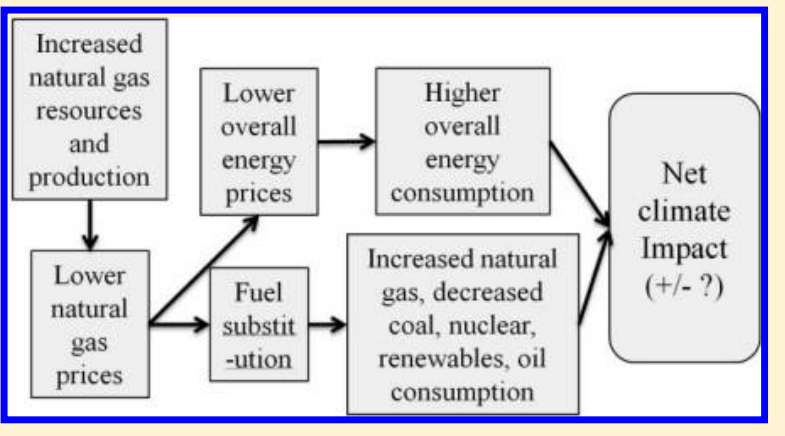
substitute this depends on the electricity mix displaced. Modeling suggests that absent substantial policy changes, increased natural gas production slightly increases overall energy use, more substantially encourages fuel-switching, and that the combined effect slightly alters economy wide GHG emissions; whether the net effect is a slight decrease or increase depends on modeling assumptions including upstream methane emissions. Our main conclusions are that natural gas can help reduce GHG emissions, but in the absence of targeted climate policy measures, it will not substantially change the course of global GHG concentrations. Abundant natural gas can, however, help reduce the costs of achieving GHG reduction goals.

\section{INTRODUCTION}

Advances in technologies for extracting oil and gas from shale formations have dramatically increased production in the United States. Shale gas in particular has grown rapidly, from less than one percent of U.S. production in 2000 to $34 \%$ in 2012, and projections show strong production growth continuing for the foreseeable future. ${ }^{1}$ While production from shale gas has been concentrated in North America, world shale resources are very large, potentially adding over $30 \%$ to global technically recoverable natural gas resources. ${ }^{2}$

With this abundance of natural gas comes a variety of questions. These questions include how shale gas will affect the national and global economy, local environments and communities, global energy markets, geopolitics, and more. In this paper, we focus on the implications of growing shale gas production for the climate.

First, we frame the questions that must be considered to understand the economic and environmental factors at play, followed by a discussion of how natural gas is used in the economy and how increased production is likely to affect those uses. Second, we examine evidence of emission impacts to date, and discuss modeling projections of how increased natural gas production could affect future greenhouse gas (GHG) emissions in a variety of sectors. Finally, we discuss policy issues, draw conclusions, and offer suggestions for future research.
1.1. Understanding the Key Dynamics: Emissions Accounting and Decision Making. Two lines of inquiry arise in the context of how shale gas may affect the climate, relating to (i) the measurement and accounting of GHG emissions from natural gas relative to other fuels and (ii) how business, policy, and individual decisions may affect and be affected by increased abundance of natural gas.

The first is accounting for GHG emissions from natural gas at the aggregate, sectoral, and technology-specific levels. At the aggregate level, this means understanding how much and what type of GHGs are emitted during the full lifecycle, including well development, gas processing, distribution, and combustion. At the sectoral level, this means understanding how those GHG emissions compare with other fuels competing for the same market. For example, what is the potential for substituting natural gas for coal or renewables in electricity generation, and how does the price of natural gas and any associated emissions policy influence that substitution? At the technology-specific level, emissions accounting tends to focus on the implications

Special Issue: Understanding the Risks of Unconventional Shale Gas Development

Received: October 15, 2013

Revised: April 11, 2014

Accepted: April 22, 2014

Published: April 22, 2014 
of different technologies available for the same use. ${ }^{3}$ For example, what are the emissions from natural gas compared to coal for producing electricity or compared to gasoline for transport?

Second, decisions across the economy may influence and be influenced by the increased supply of natural gas. In the natural gas and oil sectors, companies will decide among a range of technologies to control GHG emissions. These decisions include whether to capture and sell, flare, or vent excess natural gas at the well site, or whether to purchase low-bleed equipment for processing infrastructure. Government officials will make decisions with implications for GHG emissions, such as the U.S. EPA's proposed "green completion" standard. ${ }^{4}$ Natural gas prices may affect decisions on national climate policies, as inexpensive natural gas can make certain policies more attractive than others. Natural gas prices will also affect decisions by manufacturers, electric utilities, and commercial and residential energy consumers, each with implications for the climate.

Unless otherwise noted, our estimates for U.S. emissions come from the U.S. Environmental Protection Agency (EPA), ${ }^{5}$ for U.S. energy use come from the U.S. Energy Information Administration (EIA), and for global energy use and emissions come from the International Energy Agency (IEA). For forward-looking projections, we focus on projections from the U.S. EIA, which includes in its 2013 Annual Energy Outlook a High Oil and Gas Case, where estimated ultimate recovery of domestic natural gas and oil is roughly double that of the Reference Case. For international projections, we turn mainly to the IEA, which in 2011 produced a modeling scenario called the Golden Age of Gas, where global production and consumption of natural gas is assumed to increase substantially (see Supporting Information). We caution the reader not to rely heavily on the precise magnitude of the simulation results, however, which are subject to both data and model uncertainty that are unquantified.

1.2. Natural Gas Use and Greenhouse Gas Emissions in the United States. U.S. dry natural gas production of 24.1 trillion cubic feet (Tcf) in 2012 satisfied $94 \%$ of the $25.5 \mathrm{Tcf}$ of U.S. natural gas consumed in 2012. ${ }^{6}$ Consumption was split between residential and commercial buildings (7.1 Tcf), industrial users (7.1 Tcf), and electricity generation (9.1 Tcf). ${ }^{7}$ Although the majority of recent research on GHG emissions from natural gas has focused on electricity generation, most natural gas goes to other applications. This research focus is understandable, as fuel switching between natural gas and other fuels can happen relatively quickly in the electricity sector. However, this relatively narrow focus limits the potential to understand the full GHG implications of shale gas.

EPA's 2013 GHG inventory estimated that U.S. GHG emissions in 2011 were 6.7 billion metric tons of $\mathrm{CO}_{2}$ equivalent $\left(\mathrm{CO}_{2} \mathrm{e}\right)$, the lowest annual level since $1995 .{ }^{5}$ Eightyfive percent of these emissions were energy-related, with natural gas, coal, and oil comprising 26\%, 34\%, and 40\% of emissions, respectively. The vast majority (90\%) of total GHG emissions from natural gas are from combustion-related $\mathrm{CO}_{2}$, although methane emissions are an important contributor to the overall GHG footprint of natural gas (10\%). EPA estimates of methane emissions from natural gas systems comprise $25 \%$ of all U.S. methane emissions, with other significant sources being livestock (32\%), landfills (18\%), coal mining (11\%), and petroleum systems (5\%). EPA's estimates of 2011 emissions assume a global warming potential (GWP) for methane of 21 over a 100 -year time frame, substantially lower than in some other accounting (see Supporting Information).

1.3. Economic and Emission Implications of Increased Shale Gas Supply. Because natural gas markets and prices are principally regional rather than global, increased U.S. production has meant substantially lower prices for U.S. consumers. Lower natural gas prices have two primary effects, on overall energy consumption and on fuel substitution, with potentially divergent implications for GHG emissions (see Supporting Information for representative diagrams).

The first effect is that lower natural gas prices tend to lower overall energy prices, which encourages consumers to use more energy in aggregate. As consumers use more energy, GHG emissions would tend to increase. The other effect of lower natural gas prices is fuel substitution. With lower natural gas prices, users will consume more natural gas and less of other sources such as coal, oil, nuclear, renewables, and electricity. If natural gas primarily displaces coal and oil, emissions will tend to decrease. If it primarily displaces nuclear and renewables, emissions will tend to rise. If it displaces electricity in end-use applications, emissions will tend to decrease, though this depends on the electricity fuel mix. The key questions for climate are does fuel substitution increase or decrease emissions on net, and if it decreases emissions, is this effect overwhelmed by increased emissions from increased aggregate energy use? Additionally, policy measures can affect the production of natural gas, encourage the use of certain fuel types through regulation, taxes, or subsidies, and directly regulate GHG emissions.

To understand the magnitude of the potential impact of lower natural gas prices on aggregate energy use, let us place it in the context of overall energy use and the U.S. economy. In 2010, natural gas expenditures of $\$ 160$ billion comprised roughly $1 \%$ of U.S. GDP ( $\$ 15$ trillion) and 13\% of total U.S. energy expenditures ( $\$ 1.2$ trillion $){ }^{8}$ Because natural gas is only a small share of overall energy expenditures, and an even smaller share of overall consumption (i.e., GDP), we would not expect lower natural gas prices to produce a major change in overall energy use. Instead, macro factors, such as population growth, overall economic growth, and the composition of GDP (i.e., the share of services versus manufacturing in the economy), tend to dominate trends in energy use in the United States and globally.

In contrast, we would expect lower natural gas prices to more substantially affect fuel substitution. In the short term, natural gas can substitute for coal and oil through electricity generation dispatch decisions. In the longer term, low natural gas prices will affect investment decisions, such as power plants (displacing coal, nuclear, and renewables), heating systems (displacing electricity and fuel oil), industrial uses (displacing electricity, coal, and petroleum), and perhaps transportation (displacing petroleum, biofuels, and electricity).

Economists use demand elasticities to measure the responsiveness of consumers to changes in price. Demand elasticities summarize both near-term effects such as fuel switching, as well as longer-term effects such as technology deployment decisions. ${ }^{9}$ Models such as EIA's National Energy Modeling System (NEMS) embody a variety of elasticities that, though uncertain, can help us estimate the magnitude of responsiveness to price changes.

For example, a demand elasticity of -1 for aggregate energy consumption would tell us that as natural gas prices decrease by 
$10 \%$, aggregate energy use increases by $10 \%$. The demand elasticities embodied in NEMS are low (less than -0.1) for the medium- and long-run effect of low natural gas prices on aggregate energy demand (see Supporting Information for detail on elasticity computations). In contrast, the fuel substitution effects are more substantial. In the residential, commercial, and industrial sectors, NEMS embodies moderate elasticities of natural gas demand with respect to natural gas prices of -0.1 to -0.5 over the mid to long term. In the electricity sector, where fuel substitution is easiest, NEMS implies large elasticities in the medium term (-2.4 in 2020) and in the longer term (-1.4 in 2040).

These elasticities suggest several things: First, low natural gas prices are likely to have a small effect on economy-wide energy use. Second, we see a modest effect in terms of encouraging fuel switching in the residential, commercial, and industrial sectors. Third, low natural gas prices appear to have a strong effect in encouraging electricity generators to switch from other fuels such as coal, nuclear, or renewables.

\section{GREENHOUSE GAS IMPLICATIONS OF INCREASED NATURAL GAS SUPPLY}

Low natural gas prices-along with other factors including slow economic growth, increased efficiency, new power-sector regulations, and state/federal support for renewable electricity-have decreased U.S. GHG emissions from their peak in 2007. Dissecting historical emission changes into the underlying causes can be complex, however, and understanding the future implications of increased natural gas supply for GHG emissions is more challenging still.

In the remainder of this section, we review the evidence on GHG emissions from natural gas systems, and for the use of natural gas relative to other fuels for electricity, residential and commercial buildings, transport, and industry. We then review limited projections of aggregate impacts of increased natural gas supply on U.S. and international GHG emissions.

2.1. Methane and Other GHG Emissions from Natural Gas Systems. One issue to address before detailing our findings is the amount of methane that escapes from natural gas and petroleum systems, that is from systems upstream of enduse combustion, including production, processing, and transportation of natural gas.

If methane, the primary component of natural gas, is released into the atmosphere instead of being combusted, the lower $\mathrm{CO}_{2}$ emissions associated with combustion of natural gas relative to coal and oil is partly offset; how great this offset is has become an important question. The difference between methane's medium-term (20-year) and longer-term (100-year) climate impact relative to $\mathrm{CO}_{2}$ also plays into this discussion. ${ }^{10}$ Because most climate change discussion has centered on longterm stabilization, however, the principal focus has been on 100-year GWPs. EPA's 2013 estimates of 2011 emissions assume a 100-year GWP of 21 for methane, though this number is low relative to the Intergovernmental Panel on Climate Change (IPCC) Fifth Assessment Report, which uses a 100-year GWP of 34 for methane (see Supporting Information).

According to the 2013 EPA GHG Inventory, methane emissions from natural gas systems accounted for roughly 146 million tons of $\mathrm{CO}_{2} \mathrm{e}$ in 2011 , equal to roughly $10 \%$ of all natural-gas related GHG emissions and $1.3 \%$ of gross U.S. natural gas withdrawals in 2011. Assuming a GWP of 34, methane emissions from natural gas systems would be closer to
$15 \%$ of all natural gas-related GHG emissions. Estimates from the U.S. EIA and EPA indicate that as natural gas production has surged, overall methane emissions have declined, resulting in a $23 \%$ decrease in methane emissions per unit of gross natural gas withdrawals from 2007 to 2011 . However, EPA has revised their methodology on methane emissions several times in recent years, because of changes in both evidence and modeling assumptions, highlighting the uncertainty surrounding this issue. Additionally, we note that the integrated nature of natural gas and petroleum liquids production creates challenges in allocating methane emissions to different sectors (see Supporting Information).

Academia, industry, and NGOs have been trying to better characterize methane emissions, in part by conducting lifecycle GHG assessments of shale gas and "conventional" gas, then comparing those assessments to other sources such as coal for electricity, gasoline for vehicles, and other uses. Most of these studies have estimated that upstream methane and $\mathrm{CO}_{2}$ emissions are small relative to the $\mathrm{CO}_{2}$ emitted when natural gas is combusted for electricity, heating, or other uses. ${ }^{10-20} \mathrm{An}$ important note is that many-though not all-of these studies rely on EPA data of various vintages, which has seen significant revisions in recent years.

A smaller set of studies suggest that methane emissions may be significantly higher. One study by Howarth et al. ${ }^{21}$ estimates that up to $7.9 \%$ of methane produced during the lifetime of a well escapes, negating the GHG benefits of natural gas relative to coal for electricity production. However, this study relies on several unlikely or incorrect assumptions: that all methane is vented at the well pad, that natural gas transmission infrastructure is significantly more "leaky" than is generally assumed, and that no GHG benefit is derived from the greater efficiency of combusting natural gas relative to coal. ${ }^{22}$

Atmospheric measurements taken near oil and gas fields have suggested high methane emissions in some locations. ${ }^{23-26}$ This work generally does not make a distinction between new production sites and legacy wells or infrastructure, which may be decades old and consequently have higher emissions. Additionally, the precise source (i.e., oil and gas production, livestock cultivation, landfills, etc.) of these methane emissions is typically not clear. Thus, the implication for understanding the climate impacts of new gas development is unclear.

Some recent contributions are noteworthy. Allen et al. ${ }^{27}$ arrive at methane emission estimates similar to EPA's most recent values based on sampling at natural gas production sites. They find methane emissions during production and completion were far lower than EPA's estimates, while emissions from sources such as pneumatic devices were substantially higher. Second, nationwide measurements by Miller et al. ${ }^{28}$ indicate that, in some regions, methane concentrations are much higher than implied by EPA emissions estimates and that nationwide methane emissions may be $50 \%$ higher than EPA estimates. However, the share of this "extra" methane that is attributable to oil and gas systems is not certain. Brandt et al. ${ }^{29}$ gather a variety of studies and similarly suggest that methane emissions are roughly 50\% higher than EPAs estimates, though, again, the precise sourcing of these emissions presents challenges.

These studies are in some ways complementary. The first finds that emissions at recent production sites are roughly in line with EPA estimates, while the others suggest that system-wide emissions may be higher. If higher-than-expected methane emissions are coming from older sites or infrastructure, this 
would help explain the divergence. However, substantial work is needed, and is ongoing, to better quantify the extent of anthropogenic methane emissions. Due to these uncertainties, we present results based on a range of potential methane emissions scenarios: one where methane emissions from natural gas systems are 25\% lower than EPA's estimates, one where they are equal to EPA's estimates, and one where they are $50 \%$ higher.

2.2. Electricity. 2.2.1. Recent Impacts and Lifecycle Emission Estimates. As benchmark (Henry Hub) natural gas prices fell from an average of $\$ 8.86$ per million British thermal units (Btu) in 2008 to $\$ 2.75$ in 2012, natural gas increased its market share relative to coal for electricity generation. New and proposed regulations of local air pollutants such as sulfur dioxide, nitrous oxides, and mercury have also played a role in decreasing electricity generation from coal. ${ }^{30-33}$

To see the effects of this substitution, we compare two years where net electricity generation was virtually identical: 2005 and 2012. By looking at years with equal levels of net generation, we can control in a simple manner for the impact of the interceding recession. As shown in Figure 1, net electricity

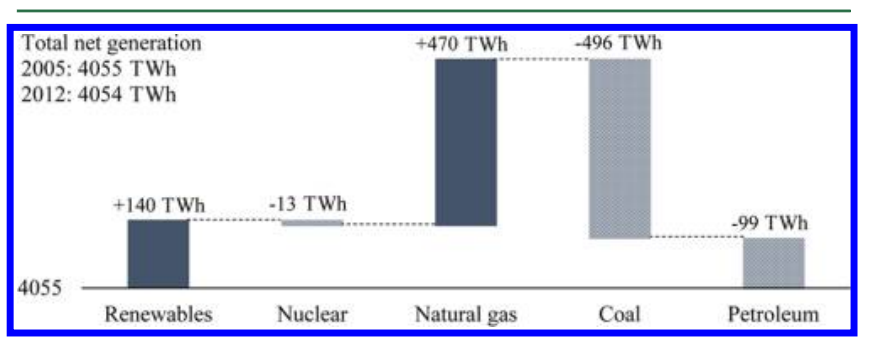

Figure 1. 2012 Electricity fuel mix compared with 2005. Source: U.S. Energy Information Administration (2013). An additional change of $\sim 2 \mathrm{TWh}$ of net generation is attributable to other small generation sources.

generation in 2005 and 2012 was 4055 terawatt-hours (TWh) and $4054 \mathrm{TWh}$, respectively. Coal generation decreased by 496 TWh in 2012 relative to 2005 and was nearly entirely offset by increased natural gas generation of 470 TWh. Petroleum dropped by 99 TWh, renewables (primarily new wind) grew by 140 TWh and nuclear generation declined by 13 TWh. Because of this new fuel mix, $\mathrm{CO}_{2}$ emissions from the electricity sector in 2012 were $16 \%$ lower than in 2005 .

Because electricity generation from natural gas emits roughly half the $\mathrm{CO}_{2}$ of coal, while nuclear and renewables emit essentially no $\mathrm{CO}_{2}$, a simple rule of thumb can help estimate the net $\mathrm{CO}_{2}$ impacts of natural gas substitution for electricity generation. If natural gas displaces more coal than it displaces renewables and nuclear, net $\mathrm{CO}_{2}$ emissions will decrease. It would appear that natural gas has primarily displaced coal in the electricity sector, resulting in lower $\mathrm{CO}_{2}$.

But natural gas has also displaced some investment in renewables and nuclear. Davis ${ }^{34}$ provides evidence on how low natural gas prices have delayed investments in new nuclear generation and plant uprates in the United States, and low natural gas prices were one factor cited by the operator of a soon-to-close nuclear plant in Vermont. ${ }^{35}$ Natural gas is competing with renewables for investment dollars, as $77 \%$ of new generating capacity in 2012 came from natural gas (32\%) and wind $(45 \%)$. One recent analysis from Bolinger ${ }^{38}$ describes how new wind projects have struggled to compete with new natural gas plants, even taking into account incentives for wind power.
2.2.2. Projected Future Impacts. Looking forward, the EIA NEMS model projects that increased production of natural gas will continue to displace coal, nuclear and renewables, though the larger impact will be to coal. Under the 2013 EIA High Oil and Gas Case, natural gas prices for electricity generation are $39 \%$ lower than the Reference Case in 2040, and electricity prices are $14 \%$ lower economy-wide. Overall electricity consumption is $4.2 \%$ higher, and-all else equal-this would increase GHG emissions. However, the composition of the fuel mix results in the opposite effect: the substitution effect dominates the aggregate demand effect. In 2040 under the High Oil and Gas Case, natural gas produces 600 TWh more electricity than under the Reference Case. This increased generation comes at the expense of coal, which produces 400 TWh less; renewables, which produce 125 TWh less; and nuclear, which produces $50 \mathrm{TWh}$ less than the Reference Case.

Natural gas displaces more coal than renewables and nuclear, and as suggested by our rule of thumb, GHG emissions between 2010 and 2040 from the electricity sector are a cumulative $5.1 \%$ lower under the High Oil and Gas Case. If we assume instead that methane emissions from natural gas systems are 50\% higher than EPA estimates, cumulative electricity emissions would still be $4.6 \%$ lower in the High Oil and Gas Case. If methane emissions were $25 \%$ lower than EPA's estimates, cumulative electricity GHG emissions would be 5.4\% lower (for details on our calculations of GHG emissions, which adjust EIA's $\mathrm{CO}_{2}$-only estimates to include methane and nitrogen oxide, see Supporting Information). If we use a methane GWP of 34 instead of 21, cumulative GHG emissions are $3.8 \%, 4.5 \%$, and $4.9 \%$ lower assuming methane emissions from natural gas systems are, respectively, 50\% higher, equal to, and $25 \%$ lower than EPAs estimates.

In a similar analysis, Logan et al. $^{20}$ projects that under a midlevel natural gas production scenario, electricity-sector emissions would be $5 \%$ lower in 2050 relative to a low natural gas production scenario in which wind and new coal plants generate more power.

2.3. Residential and Commercial Buildings. 2.3.1. Lifecyle Emission Estimates. Roughly one-third of U.S. natural gas is used in homes and businesses, where it is combusted on-site to heat water and space. Unfortunately, research on GHG emissions for natural gas technologies in residential and commercial buildings is quite limited.

In general, direct use of natural gas for heating will tend to be more efficient, and hence less GHG-intensive, than electric furnace systems, since generating electricity involves substantial efficiency losses during combustion of the fuel and transmission of the electricity. However, if electric heating systems are supplied with low-GHG fuel sources, such as nuclear or renewables, lifecycle emissions from electric systems will tend to be lower than those using natural gas. Electric heat pumps can be more efficient than either technology, but are substantially less common in U.S. homes. ${ }^{37}$

Depending on the electricity fuel mix, natural gas heating systems in most parts of the country will tend to have a lower GHG footprint than electric furnace systems. Two studies examining the lifecycle GHG emissions of natural gas for space heating relative to electricity find that, under most scenarios, natural gas systems will be roughly 50\% less GHG-intensive than electricity. ${ }^{38,39}$ As for water heating, one study from the Gas Technology Institute finds that natural gas systems are less $\mathrm{CO}_{2}$-intensive than electricity in 46 out of 50 states, and that in most states, natural gas is roughly $60 \%$ less $\mathrm{CO}_{2}$ intensive. ${ }^{40}$ 
The U.S. electricity grid as a whole is becoming less GHGintensive, which will make electric heating systems more climate-friendly. Additionally, high levels of methane emissions from natural gas systems would decrease the climate benefits of natural gas heating.

2.3.2. Projected Future Impacts. Our calculations based on EIA modeling results project that cumulative GHG emissions from 2010 to 2040 would be $3.3 \%$ lower in the residential and commercial sectors under the High Oil and Gas Case than in the Reference Case $(-3.0$ to $-3.3 \%$ based on the sensitivities described above regarding methane emissions from natural gas systems and its GWP). This decrease in emissions occurs despite lower energy prices and increased consumption of electricity and natural gas in the residential/commercial sector, trends that would suggest increased emissions (see Supporting Information).

So why would residential/commercial emissions fall despite relative increases in overall energy use and in all major heating technologies? The primary factor is a decrease in GHG emissions associated with residential and commercial electricity consumption. Although residential and commercial GHG emissions from direct use of natural gas are roughly 650 million metric tons greater under EIA's High Oil and Gas Case, emissions associated with electricity use are over 2600 million metric tons lower because of a less GHG-intensive fuel mix, resulting in a net emissions decrease.

2.4. Transportation. Increased U.S. natural gas production has also increased interest in natural gas as a transportation fuel as compressed natural gas (CNG), liquefied natural gas (LNG), or other natural gas-derived fuels. ${ }^{41,42}$ However, infrastructural challenges and high initial equipment cost have limited its adoption to date. Greater near-term potential for fuel switching exists for vehicles that either return regularly to a central fueling station (e.g., fleet vehicles) or vehicles that travel standardized routes (e.g., long-haul trucks).

A variety of lifecycle analyses show that CNG-fueled passenger vehicles tend to have a $10-30 \%$ GHG benefit relative to gasoline on a per-mile traveled basis. ${ }^{15,18,43-45}$ As for heavy vehicles such as trucks and buses, the evidence is mixed. Some studies estimate 10-25\% lower lifecycle GHGs for CNG and LNG buses relative to diesel, ${ }^{43,46}$ while others estimate that CNG buses and trucks have an equal or greater lifecycle GHG footprint relative to diesel. ${ }^{10,15,18}$ We do not present projection results here, as none of EIA's modeling scenarios entail widespread adoption of natural gas vehicles. However, increased oil production and lower oil prices lead to substantially higher transportation-related GHG emissions under the High Oil and Gas Case.

2.5. Industrial Uses. In the industrial sector, natural gas is used for process heating by metals manufacturers, industrial boilers, petroleum refiners, and as feedstock by bulk chemicals producers. Increased natural gas production and associated lower prices has led to significant new investment in the United States by some of these industries. As prices fall, industrial users will tend to consume more natural gas, increasing on-site GHG emissions from gas consumption.

However, a potentially countervailing issue relates to international trade and consideration of global emissions rather than solely U.S. emissions. Consider an industrial natural gas user choosing to invest in the United States rather than another country (where environmental regulations may be weaker). If the company's investment and production somewhere were inevitable, a plausible scenario assuming a given level of global industrial production, investment in the United States instead of another country because of low natural gas prices could imply a global GHG emissions decrease, although U.S. emissions would rise.

There is also the potential for fuel switching in the industrial sector, which consumes significant amounts of electricity and some coal. Low natural gas prices would encourage fuel switching away from these two sources and toward natural gas, with similar GHG implications as discussed in sections 2.2 and 2.3. Fuel switching away from coal will tend to decrease GHG emissions, while fuel switching away from electricity will typically decrease emissions, though this depends on location and could change over time.

Despite some recent attention to the GHG implications of increased natural gas production for the industrial sector, ${ }^{47}$ we are not aware of any work that investigates the factors described above in detail.

Looking forward, under EIA's High Oil and Gas Case, natural gas prices for industrial consumers are 39\% lower and aggregate energy demand is $7 \%$ higher $(+2.1$ Quadrillion Btu (QBtu)) in 2040 relative to the Reference Case. Most of that new industrial energy demand comes from natural gas, with a smaller increase in electricity consumption, and a decrease in coal consumption, though the relatively small amount of coal consumption in the industrial sector makes this change less consequential. The net effect of these changes is a $0.4 \%$ increase in cumulative U.S. industrial GHG emissions from 2010 through 2040 relative to the Reference Case $(+0.7$ to $+0.2 \%$ based on the sensitivities described above). This increase is not trivial but is lower than one might expect given the increase in overall industrial energy consumption of $7 \%$ in 2040. Additionally, industrial GHG emissions could decrease internationally because of greater industrial production in the United States.

2.6. Aggregate U.S. GHG Impacts of Increased Shale Gas Supply. In aggregate, our calculations based on EIA NEMS results project that high natural gas production would slightly alter economy-wide GHG emissions from what they would otherwise be. Whether the net effect is an increase or decrease depends on modeling assumptions including upstream methane emissions. Under EIA's 2013 High Oil and Gas Case, natural gas prices would be $45 \%$ lower across the economy relative to the Reference Case in 2040. Total energy use is 3\% higher and GDP is one percent higher-trends that would tend to increase GHG emissions if the mix of fuels remained constant. However, cumulative 2010-2040 GHG emissions from all sectors are $0.3 \%$ lower than the Reference Case (sensitivity cases including all sectors range from +0.3 to $-0.5 \%)$.

If we exclude emissions from the transportation sector, where emissions increase in this scenario due primarily to higher oil (rather than gas) production, cumulative economy-wide emissions from 2010 to 2040 would be $1.4 \%$ lower than the Reference Case (sensitivity cases range from -0.4 to $-1.6 \%$ ). This decrease in emissions indicates that under this set of modeling assumptions, the effect of substituting toward natural gas from other fossil fuels is on the whole greater than the effect on aggregate energy demand. As shown in Figure 2, the presumed GWP of methane and the level of methane emissions from natural gas systems plays an important role in these estimates. Additional changes in modeling assumptions would also affect these results, yielding outcomes that could imply slight increases (rather than decreases) in aggregate emissions. 


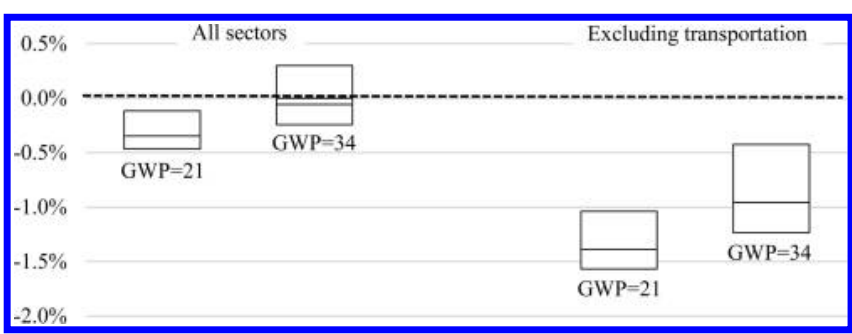

Figure 2. Cumulative 2010-2040 GHG emissions $\left(\mathrm{CO}_{2}\right.$ and $\left.\mathrm{CH}_{4}\right)$, High Oil and Gas Case. Note: Sensitivity cases assume that methane emissions from natural gas systems are either $25 \%$ lower or $50 \%$ higher than estimated by EPA in its 2013 Annual Inventory of Greenhouse Gas Emissions and Sinks. GWP refers to alternative values for the 100year GWP of methane. Results excluding transportation focus on natural gas-related emission changes by excluding transportation, which is mostly oil-based. The High Oil and Gas Case and the Reference Case are based on the U.S. Energy Information Administration 2013 Annual Energy Outlook.

These results suggest that increased natural gas production is likely to have a small effect on aggregate U.S. GHG emissions. The climate benefits that are achievable through substitution for coal in the electricity sector are significant, but unlikely to substantially alter the aggregate GHG trajectory in the absence of GHG reduction policies. At the same time, a relatively high level of methane emissions from natural gas systems is unlikely to dramatically increase the trajectory of GHG emissions.

Other modeling projections find similarly modest effects. One recent evaluation of a variety of projections shows that economy-wide GHG emissions with abundant natural gas production are not significantly different to GHG emissions without abundant natural gas, ${ }^{48}$ with some models showing high natural gas production slightly increasing GHG emissions, and others showing the opposite.

2.7. International Implications. 2.7.1. Recent Impacts. Although significant investment in shale development outside North America has begun, there is little to no commercial-scale production as of this writing. As such, current international climate impacts would be principally related to indirect international trade implications of U.S. shale development, such as those identified in section 2.5.

One such international issue is the recent increase in U.S. coal exports. These new exports raise an important question: are GHG reductions in the United States from substituting natural gas for coal being offset by the GHG emissions arising from exported coal combusted outside the United States?

The issue of attributing emissions in a globalized economy is complex, ${ }^{49}$ and we address the question two ways. First, overall GHG emissions attributable to U.S. coal, whether consumed domestically or abroad, will be roughly proportional to the overall production of coal in the United States. We can get a sense of how increased natural gas production has affected these trends by comparing 2008, when shale gas production began to substantially push down U.S. natural gas prices, with 2012. Over the 2008-2012 period, we see that gross coal exports increased by 44 million short tons. However, U.S. coal production fell by 155 million short tons over the same time period (consumption fell by 230 million short tons). Such a large production decrease demonstrates that increased coal exports has not negated the GHG benefits associated with decreasing U.S. coal consumption.

Second, we can consider the issue from a global market perspective. U.S. net coal exports in 2012 accounted for roughly
$8 \%$ of global coal trade. ${ }^{50}$ If increased U.S. coal exports are pushing down global coal prices, they will tend to increase global coal consumption and associated emissions. However, if U.S. exports are primarily displacing exports from other regions and not substantially affecting prices, global coal consumption would tend to not be affected by these increased exports.

One recent report from the IEA $^{51}$ argues that natural gas' displacement of coal for electricity generation in the United States led to increased coal consumption in Europe in 2012, though the report projected that this trend is unlikely to persist. Additionally, increased European coal consumption may have been met by other suppliers were U.S. coal not available. Darmstadter ${ }^{52}$ argues that increased U.S. coal exports primarily displace exports from other regions. Additional research on the global market effects of increased U.S. coal exports is needed to shed more light on this issue.

2.7.2. Projected Future Impacts. A global surge in natural gas production would have many of the same aggregate demand and substitution effects that we have discussed for the United States. Large-scale production of shale gas in countries heavily reliant on coal for electricity has the potential to decrease GHG emissions from what they would otherwise be. Increased trade in LNG also has the potential to reduce GHG emissions, as LNG-despite the energy consumed through liquefaction and transport-tends to have a lower lifecycle GHG footprint than coal. ${ }^{12,18,53}$ However, to the extent natural gas displaces zero-GHG sources such as nuclear and renewables or suffers from high levels of methane emissions from natural gas systems, this would lessen the GHG benefits internationally.

One useful assessment of how increased natural gas production could affect GHG emissions comes from the International Energy Agency (IEA). The IEA released in 2011 a scenario called the Golden Age of Gas (GAS), which projected global natural gas consumption to be $13 \%$ higher in 2035 relative to their baseline case (the 2010 New Policies Scenario), with shale and other "unconventional" formations contributing $40 \%$ of new supply. Under the GAS Scenario, global average natural gas prices are roughly $\$ 1.50-\$ 2.00$ per million Btu below the baseline case. We would expect lower energy costs to increase energy consumption to some degree, and natural gas substitution for other fuels would be the key factor in determining net GHG emission impacts.

Under the GAS Scenario, global natural gas consumption is $13 \%$ higher (476 million tons of oil-equivalent, or Mtoe) in 2035 , largely substituting for coal and oil, which are 6.8\% (268 Mtoe) and 2.6\% (119 Mtoe) lower than the baseline case, respectively. This would tend to reduce emissions. However, overall energy demand is slightly higher $(0.1 \%$, or 17 Mtoe) under the GAS Scenario. Additionally, natural gas displaces nuclear power, which is $6 \%$ lower ( $77 \mathrm{Mtoe}$ ), and to a lesser extent renewables, whose contribution is $0.4 \%$ lower $(14 \mathrm{Mtoe})$ in 2035 .

Under the GAS Scenario, global $\mathrm{CO}_{2}$ emissions are less than one percent lower in 2035 relative to the 2010 baseline case. Another projection by Edmonds and McJeon ${ }^{54}$ estimates that increased natural gas production would have little effect on global emissions, as decreased coal consumption is offset by increased overall energy consumption and decreased deployment of nuclear and renewables.

\section{POLICY INTERACTIONS AND CONCLUSIONS}

3.1. Increased Natural Gas Production and Climate Policy Interactions. Increased supply of natural gas has the 
potential to decrease the costs of implementing comprehensive climate policies, but the design of the policy is important. Analyses by Jacoby et al. ${ }^{55}$ using the MIT EPPA model and Brown and Krupnick ${ }^{56}$ using the RFF-NEMS model show that in policy scenarios that constrain GHG emissions through a cap-and-trade program or a carbon tax, natural gas helps reduce the economic costs of achieving emissions targets. Logan et al. $^{20}$ similarly estimate that, under a federal clean energy standard, high natural gas production can help meet standards, while keeping electricity prices lower than without high natural gas production. Intuitively, providing a lower-cost, loweremission alternative to coal makes it easier to achieve GHG reductions.

It is also worth considering how low natural gas prices could interact with current and future regulations on coal-fired power plants. The EIA NEMS Reference Case projects that (beyond a small number of plants under construction) no new conventional coal power will be built in the United States, in part because low natural gas prices make new coal noncompetitive. As EPA implements GHG regulations on new and existing power plants, low-cost natural gas will reduce the expected economy-wide costs of meeting these new standards, since it has already forestalled new coal plants in the baseline.

However, abundant natural gas can increase the costs of other policies. For example, Jacoby et al. ${ }^{55}$ show that under a national renewable electricity standard, low natural gas prices increase the incremental cost of maintaining the standard by increasing the costs of deploying renewable sources relative to natural gas.

3.2. Conclusions. 3.2.1. Shale Gas Development Has Modestly Reduced U.S. GHG Emissions. If natural gas continues to displace more coal and petroleum than low GHG-technologies like nuclear, hydro, and renewables, it will likely be a net benefit for the climate. However, high levels of methane emissions can reduce this climate benefit, and understanding of methane emissions from natural gas systems needs improvement. As technology and policy develops, natural gas systems will likely emit less methane and combustion systems will become more efficient, which would lead to further improvement in the relative GHG-intensity of natural gas, though any turnover in this type of infrastructure stock will necessarily occur gradually.

3.2.2. Shale Gas Affects Emissions beyond Just the Electricity Sector. Although the greatest research focus has been electricity generation, it is important to examine the merits of natural gas relative to other energy sources for other applications. It appears that natural gas can have climate benefits in the residential/commercial sector relative to electricity and fuel oil, and to a lesser but still significant extent for personal transportation relative to gasoline. The GHG impacts of natural gas relative to diesel long-haul trucks and buses is less clear, in part because diesel equipment is already relatively fuel efficient.

3.2.3. Shale Gas Will Likely Not Substantially Change Global GHG Concentrations on Its Own: Policy and a Range of Competitive Low-GHG Energy Options are the Key Factors. Shale gas has led to modest GHG emissions reductions, but these are not sufficient to substantially alter the future path of global GHG concentrations. For this to happen, policies would need to provide stronger incentives to switch to existing and deploy new technologies fueled by natural gas, renewables, nuclear, and fossil fuels coupled with carbon capture and sequestration. These technologies would in turn need to become more cost-competitive and more broadly deployed on an international scale.

3.2.4. Additional Research Is Needed. For a number of the issues discussed in this paper, additional research is needed. Key areas include methane emissions from natural gas systems and other sources; the emissions profiles of natural gas versus electricity and oil-based heating systems; the GHG implications of changes in international trade patterns due to shale gas growth; and the likely magnitude of substitution of natural gas for coal versus zero-carbon electricity, both in the United States and internationally.

\section{ASSOCIATED CONTENT}

\section{Supporting Information}

Additional material as described in the text. This material is available free of charge via the Internet at http://pubs.acs.org.

\section{AUTHOR INFORMATION}

\section{Corresponding Author}

*E-mail: richard.newell@duke.edu.

\section{Notes}

The authors declare no competing financial interest.

\section{ACKNOWLEDGMENTS}

The authors acknowledge helpful comments from four anonymous reviewers, Jason Bordoff, Paul Stern, Chris Weber, and other participants in a National Academy of Sciences workshop on shale gas.

\section{REFERENCES}

(1) U.S. Energy Information Administration. Annual Energy Outlook, DOE/EIA-0383ER(2013); U.S. Energy Information Administration: Washington, DC, 2013.

(2) U.S. Energy Information Administration. Technically Recoverable Shale Oil and Shale Gas Resources: An Assessment of 137 Shale Formations in 41 Countries Outside the United States; U.S. Energy Information Administration: Washington, DC, 2013.

(3) International Organization for Standardization. Environmental Management-Life Cycle Assessment-Principles and Framework; International Organization for Standardization: Geneva, 2010.

(4) Environmental Protection Agency. Proposed Amendments to Air Regulations for the Oil and Natural Gas Industry. http://www.epa. gov/airquality/oilandgas/pdfs/20110728factsheet.pdf (accessed July 2, 2013).

(5) U.S. Environmental Protection Agency. Inventory of U.S. Greenhouse Gas Emissions and Sinks: 1990-2011, EPA 430-R-13-001; U.S. EPA: Washington, D.C., 2013.

(6) U.S. Energy Information Administration. Natural Gas Gross Withdrawals and Production. http://www.eia.gov/dnav/ng/ng_prod_ sum_dcu_NUS_a.htm (accessed Feb. 14, 2013).

(7) U.S. Energy Information Administration. Natural Gas Consumption by End Use. http://www.eia.gov/dnav/ng/ng_cons_ sum_dcu_nus_a.htm (accessed Feb. 14, 2013).

(8) U.S. Energy Information Administration. Annual Energy Review, DOE/EIA-0384(2011); U.S. Energy Information Administration: Washington, DC, 2012.

(9) Venkatesh, A.; Jaramillo, P.; Griffin, W. M.; Matthews, H. S. Implications of Near-Term Coal Power Plant Retirement for SO2 and NOX and Life Cycle GHG Emissions. Environ. Sci. Technol. 2012, 46 (18), 9838-9845.

(10) Alvarez, R. A.; Pacala, S. W.; Winebrake, J. J.; Chameides, W. L.; Hamburg, S. P. Greater Focus Needed on Methane Leakage from Natural Gas Infrastructure. Proc. Natl. Acad. Sci. U. S. A. 2012, 109 (17), 6435-6440. 
(11) Jiang, M.; Griffin, W. M.; Hendrickson, C.; Jaramillo, P.; VanBriesen, J.; Venkatesh, A. Life Cycle Greenhouse Gas Emissions of Marcellus Shale Gas. Environ. Res. Lett. 2011, 6 (3), No. 034014.

(12) Skone, T. J.; Littlefield, J.; Marriott, J. Life Cycle Greenhouse Gas Inventory of Natural Gas Extraction, Delivery, and Electricity Production, DOE/NETL-2011/1522; National Energy Technology Laboratory: Morgantown, WV, 2011.

(13) Hultman, N.; Rebois, D.; Scholten, M.; Ramig, C. The Greenhouse Impact of Unconventional Gas for Electricity Generation. Environ. Res. Lett. 2011, 6 (4), No. 044008.

(14) Stephenson, T.; Valle, J. E.; Riera-Palou, X. Modeling the Relative GHG Emissions of Conventional and Shale Gas Production. Environ. Sci. Technol. 2011, 45 (24), 10757-10764.

(15) Burnham, A.; Han, J.; Clark, C. E.; Wang, M.; Dunn, J. B.; Palou-Rivera, I. Life-Cycle Greenhouse Gas Emissions of Shale Gas, Natural Gas, Coal, and Petroleum. Environ. Sci. Technol. 2011, 46 (2), 619-627.

(16) Weber, C. L.; Clavin, C. Life Cycle Carbon Footprint of Shale Gas: Review of Evidence and Implications. Environ. Sci. Technol. 2012, 46 (11), 5688-5695.

(17) O'Sullivan, F.; Paltsev, S. Shale Gas Production: Potential versus Actual Greenhouse Gas Emissions. Environ. Res. Lett. 2012, 7 (4), No. 044030.

(18) Venkatesh, A.; Jaramillo, P.; Griffin, W. M.; Matthews, H. S. Uncertainty in Life Cycle Greenhouse Gas Emissions from United States Gas End-Uses and Its Effects on Policy. Environ. Sci. Technol. 2011, 45 (19), 8182-8189.

(19) Dale, A. T.; Khanna, V.; Vidic, R. D.; Bilec, M. M. Process Based Life-Cycle Assessment of Natural Gas from the Marcellus Shale. Environ. Sci. Technol. 2013, 47 (10), 5459-5466.

(20) Logan, J.; Lopez, A.; Mai, T.; Davidson, C.; Bazilian, M.; Arent, D. Natural Gas Scenarios in the U.S. Power Sector. Energy Economics 2013, 40 (0), 183-195.

(21) Howarth, R. W.; Santoro, R.; Ingraffea, A. Methane and the Greenhouse-Gas Footprint of Natural Gas from Shale Formations. Clim. Change 2011, 106 (4), 679-690.

(22) Cathles, L., III; Brown, L.; Taam, M.; Hunter, A. A Commentary on "The Greenhouse-Gas Footprint of Natural Gas in Shale Formations" by R.W. Howarth, R. Santoro, and Anthony Ingraffea. Clim. Change 2012, 113 (2), 525-535.

(23) Pétron, G.; Frost, G.; Miller, B. R.; Hirsch, A. I.; Montzka, S. A.; Karion, A.; Trainer, M.; Sweeney, C.; Andrews, A. E.; Miller, L.; Kofler, J.; Bar-Ilan, A.; Dlugokencky, E. J.; Patrick, L.; Moore, C. T.; Ryerson, T. B.; Siso, C.; Kolodzey, W.; Lang, P. M.; Conway, T.; Novelli, P.; Masarie, K.; Hall, B.; Guenther, D.; Kitzis, D.; Miller, J.; Welsh, D.; Wolfe, D.; Neff, W.; Tans, P. Hydrocarbon Emissions Characterization in the Colorado Front Range: A Pilot Study. J. Geophys. Res.: Atmos. 2012, 117 (D4), No. D04304.

(24) Peischl, J.; Ryerson, T. B.; Brioude, J.; Aikin, K. C.; Andrews, A. E.; Atlas, E.; Blake, D.; Daube, B. C.; de Gouw, J. A.; Dlugokencky, E.; Frost, G. J.; Gentner, D. R.; Gilman, J. B.; Goldstein, A. H.; Harley, R. A.; Holloway, J. S.; Kofler, J.; Kuster, W. C.; Lang, P. M.; Novelli, P. C.; Santoni, G. W.; Trainer, M.; Wofsy, S. C.; Parrish, D. D. Quantifying Sources of Methane Using Light Alkanes in the Los Angeles Basin, California. J. Geophys. Res.: Atmos. 2013, 118 (10), 4974-4990.

(25) Karion, A.; Sweeney, C.; Pétron, G.; Frost, G.; Michael Hardesty, R.; Kofler, J.; Miller, B. R.; Newberger, T.; Wolter, S.; Banta, R.; Brewer, A.; Dlugokencky, E.; Lang, P.; Montzka, S. A.; Schnell, R.; Tans, P.; Trainer, M.; Zamora, R.; Conley, S. Methane Emissions Estimate from Airborne Measurements over a Western United States Natural Gas Field. Geophys. Res. Lett. 2013, 4393-4397.

(26) Wennberg, P. O.; Mui, W.; Wunch, D.; Kort, E. A.; Blake, D. R.; Atlas, E. L.; Santoni, G. W.; Wofsy, S. C.; Diskin, G. S.; Jeong, S.; Fischer, M. L. On the Sources of Methane to the Los Angeles Atmosphere. Environ. Sci. Technol. 2012, 46 (17), 9282-9289.

(27) Allen, D. T.; Torres, V. M.; Thomas, J.; Sullivan, D. W.; Harrison, M.; Hendler, A.; Herndon, S. C.; Kolb, C. E.; Fraser, M. P.; Hill, A. D.; Lamb, B. K.; Miskimins, J.; Sawyer, R. F.; Seinfeld, J. H.
Measurements of Methane Emissions at Natural Gas Production Sites in the United States. Proc. Natl. Acad. Sci. U. S. A. 2013, 110 (44), 17769-17773.

(28) Miller, S. M.; Wofsy, S. C.; Michalak, A. M.; Kort, E. A.; Andrews, A. E.; Biraud, S. C.; Dlugokencky, E. J.; Eluszkiewicz, J.; Fischer, M. L.; Janssens-Maenhout, G.; Miller, B. R.; Miller, J. B.; Montzka, S. A.; Nehrkorn, T.; Sweeney, C. Anthropogenic Emissions of Methane in the United States. Proc. Natl. Acad. Sci. U. S. A. 2013, 110 (50), 20018-20022.

(29) Brandt, A. R.; Heath, G. A.; Kort, E. A.; O’Sullivan, F.; Pétron, G.; Jordaan, S. M.; Tans, P.; Wilcox, J.; Gopstein, A. M.; Arent, D.; Wofsy, S.; Brown, N. J.; Bradley, R.; Stucky, G. D.; Eardley, D.; Harriss, R. Methane Leaks from North American Natural Gas Systems. Science 2014, 343 (6172), 733-735.

(30) Burtraw, D.; Palmer, K.; Paul, A.; Woerman, M. Secular Trends, Environmental Regulations, and Electricity Markets, DP 12-15; Resources for the Future: Washington, DC, 2012.

(31) Lu, X.; Salovaara, J.; McElroy, M. B. Implications of the Recent Reductions in Natural Gas Prices for Emissions of $\mathrm{CO} 2$ from the US Power Sector. Environ. Sci. Technol. 2012, 46 (5), 3014-3021.

(32) Pratson, L. F.; Haerer, D.; Patiño-Echeverri, D. Fuel Prices, Emission Standards, and Generation Costs for Coal vs Natural Gas Power Plants. Environ. Sci. Technol. 2013, 47 (9), 4926-4933.

(33) ICF. Current State and Future Direction of Coal-Fired Power in the Eastern Interconnection, For the Eastern Interconnection States' Planning Council and the National Association of Regulatory Utility Commissioners; ICF International: Fairfax, VA, 2013.

(34) Davis, L. W. Prospects for Nuclear Power. J. Econ. Perspect. 2012, 26 (1), 49-66.

(35) Entergy. Entergy to Close, Decommission Vermont Yankee. Frequently Asked Questions, 2013. http://www.entergy.com/vy/.

(36) Bolinger, M. Revisiting the Long-Term Hedge Value of Wind Power in an Era of Low Natural Gas Prices, LBNL-6103E; Lawrence Berkeley National Laboratory: Berkley, CA, 2013.

(37) U.S. Energy Information Administration. Residential Energy Consumption Survey 2009; U.S. Energy Information Administration: Washington, DC, 2013; Table HC 6.1.

(38) Delucchi, M. A Lifecycle Emissions Model (LEM): Lifecycle Emissions from Transportation Fuels, Motor Vehicles, Transportation Modes, Electricity Use, Heating and Cooking Fuels, and Materials; U.C. Davis Institute of Transportation Studies: Davis, CA, 2003

(39) Brenn, J.; Soltic, P.; Bach, C. Comparison of natural gas driven heat pumps and electrically driven heat pumps with conventional systems for building heating purposes. Energy and Buildings 2010, 42 (6), 904-908.

(40) Czachorski, M.; Leslie, N. Source energy and emission factors for building energy consumption; American Gas Association, prepared for Natural Gas Codes and Standards Research Consortium, 2009.

(41) National Petroleum Council. Greenhouse gases and other considerations. In Future Transportation Fuels Study: Advancing Technology for America's Transportation Future; National Petroleum Council: Washington, DC, 2012.

(42) Committee on Transitions to Alternative Vehicles and Fuels. Transitions to Alternative Vehicles and Fuels; National Academies Press, National Research Council: Washington, DC, 2013.

(43) TIAX LLC. Full Fuel Cycle Assessment: Well-to-Wheels Energy Inputs, Emissions, and Water Impacts, Report for California Energy Commission; California Energy Commission: Sacramento, CA , 2007.

(44) AEA. Climate Impact of Potential Shale Gas Production in the EU; Report for the European Commission DG CLIMA AEA/R/ED57412; European Commission: Brussels, Belgium, 2012.

(45) Nigro, N.; Jiang, S. Lifecycle Greenhouse Gas Emissions from Different Light-Duty Vehicle and Fuel Pathways: A Synthesis of Recent Research; Center for Climate and Energy Solutions: Arlington, VA, 2013.

(46) Rose, L.; Hussain, M.; Ahmed, S.; Malek, K.; Costanzo, R.; Kjeang, E. A Comparative Life Cycle Assessment of Diesel and Compressed Natural Gas Powered Refuse Collection Vehicles in a Canadian City. Energy Policy 2013, 52, 453-461. 
(47) Environmental Integrity Project. Gas Rush: Increasing Greenhouse Gas Emissions from New Oil, Gas, and Chemical Plants; Environmental Integrity Project: Washington, DC, 2013.

(48) Energy Modeling Forum. Changing the Game? Emissions and Market Implications of New Natural Gas Supplies, EMF Report 26; Stanford University: Stanford, CA, 2013; Vol. 1.

(49) Peters, G. P.; Minx, J. C.; Weber, C. L.; Edenhofer, O. Growth in emission transfers via international trade from 1990 to 2008. Proc. Natl. Acad. Sci. U. S. A. 2011, 108 (21), 8903-8908.

(50) World Coal Association Coal Statistics. http://www.worldcoal. org/resources/coal-statistics/ (accessed May 9, 2013).

(51) International Energy Agency. Medium-Term Coal Market Report; International Energy Agency: Paris, 2012.

(52) Darmstadter, J. The Controversy over US Coal and Natural Gas Exports, Brief 13-01; Resources for the Future: Washington, DC, 2013. (53) Jaramillo, P.; Griffin, W. M.; Matthews, H. S. Comparative LifeCycle Air Emissions Coal, Domestic Natural Gas, LNG, and SNG for Electricity Generation. Environ. Sci. Technol. 2007, 41 (17), 62906296.

(54) Edmonds, J.; McJeon, H., Implications of Abundant Natural Gas. In Global, Long-Term Implications of Abundant Gas; Joint Global Change Research Institute: Riverdale Park, MD, 2013.

(55) Jacoby, H. D.; O'Sullivan, F.; Paltsev, S. The Influence of Shale Gas on U.S. Energy and Environmental Policy; MIT Joint Program on the Science and Policy of Global Change, Report No. 207; Massachusetts Institute of Technology: Cambridge, MA, 2011.

(56) Brown, S. P. A.; Krupnick, A. J. Abundant Shale Gas Resources: Long-Term Implications for U.S. Natural Gas Markets, Resources for the Future Discussion Paper 10-41; Resources for the Future: Washington, DC, 2010.

\section{NOTE ADDED AFTER ASAP PUBLICATION}

This paper published to the Web on May 13, 2014, with errors to the the abbreviation for terawatt hours (TWh). GWh was replaced with TWh throughout the text and also in Figure 1. The corrected version reposted on May 19, 2014. 